\title{
Potential Recovery of Silver (Ag) from X-ray Fixer Waste by Alkaline Treatment
}

\author{
Van Ryan Kristopher R. Galarpe \\ Environmental Science \& Technology/Physics Dpt \\ University of Science and Technology of Southern \\ Philippines (USTP) \\ Philippines \\ vanryankristoher.galarpe@ustp.edu.ph
}

\author{
Girlie D. Leopoldo \\ Chemistry Department \\ University of Science and Technology of Southern \\ Philippines (USTP) \\ Philippines \\ girlie_leopoldo@yahoo.com
}

\begin{abstract}
The study aims to establish a chemical method of silver recovery from $x$-ray processing fixer waste by alkaline treatment using sodium hydroxide ( $\mathrm{NaOH})$. The samples used in the study were collected from selected hospitals and radiology centers in Cagayan de Oro City, Philippines. The $\mathrm{NaOH}$ precipitation method was employed by varying the amount of $\mathrm{NaOH}$ from 8.00 $\mathrm{g}$ to $15.00 \mathrm{~g}$ per $600 \mathrm{~mL}$ of the fixer waste sample. The recovered crude silver for the two sampling periods ranged from $0.88 \mathrm{~g}$ to $2.46 \mathrm{~g}$. The method resulted to optimum recovery at $\mathrm{pH}$ 9. The One Way ANOVA indicates that there are significant differences on the amount of silver recovered when varying the amount of $\mathrm{NaOH}$ in "sampling A". The Tukey Test further reveals that there exists an evident rise in the recovered silver using $10.00 \mathrm{~g}$ to $15.00 \mathrm{~g}$ of $\mathrm{NaOH}$. In "sampling B" the amount of silver recovered does not significantly differ when varying the amount of $\mathrm{NaOH}$ used on average basis. The raw data, however, also revealed a significant rise in the amount of silver recovered using $10.00 \mathrm{~g}$ to $15.00 \mathrm{~g}$ of $\mathrm{NaOH}$ where $\mathrm{pH}$ was approximately 9.
\end{abstract}

Keywords-X-ray; fixer waste; $\mathrm{NaOH}$; recovery ; silver (Ag)

\section{INTRODUCTION}

In the advent of modernization, several researches have been established to gaze on alternative means of collecting metals with a goal of reducing the dependence on traditional ore mining and at the same time decreasing the metal content of waste materials. Silver is of no exemption with its focal demand in the market and wide consumption both in industrial and technological applications. The increasing use for silver is significant in the industry of $\mathrm{x}$-ray processing and photography. This metal is often used as component of film emulsion containing silver halide grain, commonly silver bromide $(\mathrm{AgBr})$. The silver grains in the emulsion acts as a light sensitive material responsible for image formation. During $\mathrm{x}$ ray film processing the unreacted silver halide remaining on the film reacts with the fixer solution (thiosulfate compounds) resulting to the formation of silver thiosulfate complex $[\mathrm{Ag}(\mathrm{S} 2 \mathrm{O} 3) 23-]$ in a process known as fixing. The complex produced goes with the fixer back into a tank which is subject for disposal upon several usages. The produced waste contains high concentration of silver complexes. Thus, the release of such to any body of water promotes prolonged exposure of the environment to water-soluble inorganic chemicals and pollutants. Levels of these waste chemicals can make water unfit to drink, harm fish and other aquatic life, depress crop yields, and accelerates corrosion to equipment that uses such water. Having known of the potential hazard brought by x-ray processing fixer waste, and the valued metal present, it is therefore sensible to recover the precious silver metal it contain. Several studies elsewhere recovered silver from spent X-ray fixer waste and films through the use of enzymes and alkaline solutions [1-8] but none focused directly using low cost sodium hydroxide recovery $(\mathrm{NaOH})$ method to to X-ray fixer waste. Studies in the past similarly employed other methods like electrochemistry [9-12].

This study dealt on the recovery of silver by employing the sodium hydroxide precipitation method. Several conditions were carried out for the purpose of establishing a good system of silver recovery. These conditions include varying the amount of $\mathrm{NaOH}$, and determining the $\mathrm{pH}$ of the mixture in every amount of the precipitating agent added. The study tried to recover silver from x-ray processing fixer wastes by $\mathrm{NaOH}$ precipitation and examine the effect of varying the $\mathrm{NaOH}$ amount on the silver recovery. Specifically, the study sought to answer the following questions:

1. What amount of $\mathrm{NaOH}$ and $\mathrm{pH}$ is most suitable to recover crude silver from a certain amount of $\mathrm{x}$-ray fixer waste by $\mathrm{NaOH}$ precipitation method?

2. Are there significant differences on the amount of crude silver recovered by varying the amount of $\mathrm{NaOH}$ ?

3. What is the optimum condition to recover silver from x-ray fixer waste by $\mathrm{NaOH}$ precipitation?

\section{MATERIALS AND METHODS}

\section{A. Study setting}

The fixer waste samples were collected from selected hospitals and radiology centers in Cagayan de Oro City. These include Northern Mindanao Medical Center, Capitol University Medical City, Madonna and Children's Hospital, Maria Reyna Hospital, and Microstar Diagnostic Center. The choices of the said sampling sites were based on the abundance of x-ray processing fixer wastes. The experimentations and analyses were conducted in the Chemistry Laboratory and Automotive 
Laboratory of the University of Science and Technology of Southern Philippines (USTP). Other analysis was conducted in the Department of Agriculture 10-Regional Soil Testing Laboratory.

\section{B. Sampling Scheme}

The study constitutes two sampling periods. Samples (4 to 6L) were taken per sampling period from the selected sites. Figures 1-4 show x-ray film processors and fixer waste collection from one specific site. Equal volumes of fixer wastes collected were mixed and homogenized as a composite sample prior to analysis. The composite sample was analyzed for silver recovery at three (3) trials per amount of $\mathrm{NaOH}$. The $\mathrm{pH}$ of the resulting mixture was also determined. The dried residue produced was smelted for silver extraction.

\section{Sample preparation}

Equal volumes of $\mathrm{x}$-ray processing fixer wastes from selected sampling sites were mixed. The produced composite sample was stored in a $20 \mathrm{~L}$ capacity polyethylene container.

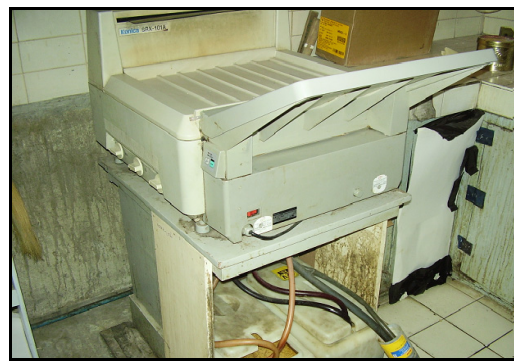

Fig. 1. X-ray machine generating spent fixer waste in Northern Mindanao Medical Center (NMMC)

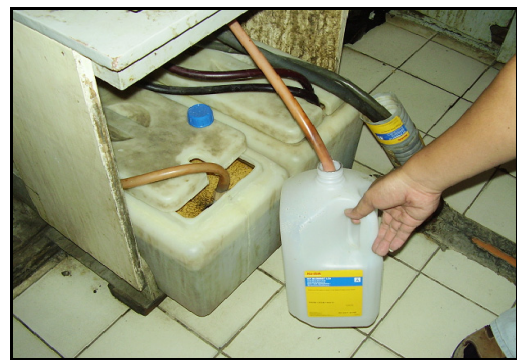

Fig. 2. Collection of spent fixer waste in Northern Mindanao Medical Center (NMMC)

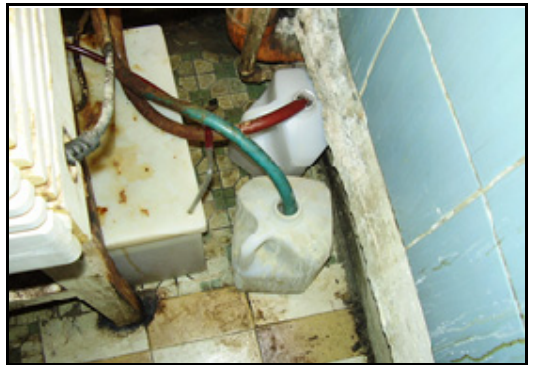

Fig. 3. Collection of spent fixer waste in a private hospital

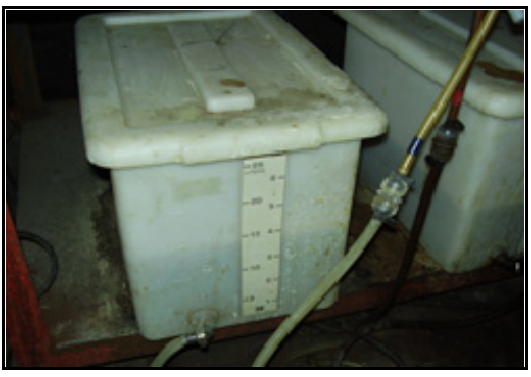

Fig. 4. Collection of spent fixer waste in a medical clinic

\section{Recovery of $\mathrm{Ag}$ by $\mathrm{NaOH}$ precipitation}

A 600-mL volume of fixer waste from the composite sample was placed into a $1000-\mathrm{mL}$ beaker. With the use of a 5 sitter Cole Parmer Magnetic Stirrer, the sample was stirred for 10 mins. A weighed amount of $\mathrm{NaOH}$ was added into the stirred sample. Another 30 minutes of stirring was applied to complete the precipitation. The $\mathrm{pH}$ of the resulting mixture was also determined using a Metler Toledo MP220 pH meter. The amounts of $\mathrm{NaOH}$ used and tried were 8.00, 9.00, 10.00, 11.00, $12.00,13.00,14.00$, and $15.00 \mathrm{~g}$. The precipitate of the produced mixture (turbid yellow to black) was allowed to settle or separate (for $24 \mathrm{~h}$ or more) from the mother liquor. The mother liquor of the resulting mixture was then collected using a measuring pipet. The remaining slurry (precipitate) was placed into a pre-weighed drying vessel covered by a watch glass and dried for three hours under low heat to prevent loss of the analyte by bumping or splattering. The dried sample was then placed in a desiccator for 30 minutes and weighed using a top-loading balance. The dried sample was scraped from the vessel using a metal spatula and transferred into a ceramic vessel and added with $2.00 \mathrm{~g}$ borax. The pulverized sampleborax mixture was then smelted using oxy-acetylene. The isolated crude silver was picked using forceps and then weighed.

\section{E. Statistical analysis}

Descriptive statistic was employed in order to get the average amount of silver recovered at different amount of $\mathrm{NaOH}$ added. One Way-Analysis of Variance (One WayANOVA) was also employed to statistically evaluate he difference on the silver recovered by varying the amount of $\mathrm{NaOH}$. Further test by the Tukey method was used to determine specific factor(s) that significantly differ statistically. Statistical tests were conducted at 0.05 level fo significance.

\section{RESULTS AND DISCUSSIONS}

\section{A. Summary of results}

As can be seen in Tables I and II, the amount of silver recovered is dependent on the amount of $\mathrm{NaOH}$. Although the result shows inconsistencies, an increase in the mass of $\mathrm{NaOH}$ generally results to an increase in silver recovery. Similarly, an increase in the $\mathrm{pH}$ of the resulting mixture generally results to an increase in silver recovery. The result of the two sampling periods indicate that a minimum of $10.00 \mathrm{~g} \mathrm{NaOH}$ was necessary to recover a significant amount of silver from 600 $\mathrm{mL}$ volume of x-ray fixer waste. The use of $10.00 \mathrm{~g} \mathrm{NaOH}$ results to a $\mathrm{pH}$ approximately near to 9 which was within the 8- 
$10 \mathrm{pH}$ range necessary for silver hydroxide precipitation to occur as stated in the literature $[1,2]$. The decrease in $\mathrm{pH}$ after adding $12.00 \mathrm{~g} \mathrm{NaOH}$ as compared to $\mathrm{pH}$ of the mixture when adding $11.00 \mathrm{~g} \mathrm{NaOH}$ was true to both sampling periods. These may be due to processes/reactions occurring in the mixture itself. The fixer waste was primarily a mixture of the silver thiosulfate complex, acetic acid, ammonium bisulfite, and sodium bisulfite. Thus these other chemical components of the fixer other than the silver complexes perhaps have interfered in the precipitation process. The inconsistencies in the silver recovered, on the other hand, may be because the silver was still crude thus resulting to the variations in the masses of the silver recovered. Confirmatory trials were actually made in order to assess if usage of increased amount (the ones employed in the study) of $\mathrm{NaOH}$ was sufficient to recover silver from the fixer waste sample. This was done by conducting two trials of the recovery study in sampling 1 using approximately $25.00 \mathrm{~g}$ of $\mathrm{NaOH}$. The results revealed that the amount of silver recovered differs only by $0.07 \mathrm{~g}$ from the average silver recovered using $14.00 \mathrm{~g}$. Thus, the use of $10.00-$ $15.00 \mathrm{~g}$ of $\mathrm{NaOH}$ can be considered appropriate amount to recover silver from $600 \mathrm{~mL}$ of $\mathrm{x}$-ray fixer waste. Figure 5 shows an example of the recovered crude silver.

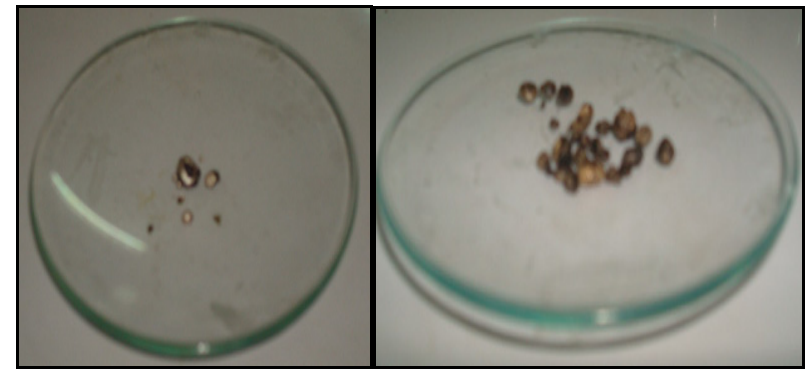

Fig. 5. Crude silver recoverd

TABLE I. SUMMARY OF RESULTS (SAMPLING PERIOD 1)

\begin{tabular}{|c|c|c|c|}
\hline Analysis no. & $\begin{array}{c}\text { Amount of } \\
\text { NaOH (g) }\end{array}$ & $\mathbf{p H}$ & $\begin{array}{c}\text { Amount of Ag } \\
\text { recovered (g) }\end{array}$ \\
\hline 1 & $8.01 \pm 0.00$ & $8.80 \pm 0.08$ & $0.88 \pm 0.34$ \\
\hline 2 & $9.07 \pm 0.01$ & $8.77 \pm 0.04$ & $1.34 \pm 0.04$ \\
\hline 3 & $10.00 \pm 0.00$ & $8.97 \pm 0.08$ & $1.70 \pm 0.21$ \\
\hline 4 & $11.03 \pm 0.02$ & $9.08 \pm 0.02$ & $1.28 \pm 0.18$ \\
\hline 5 & $12.08 \pm 0.06$ & $8.88 \pm 0.10$ & $1.71 \pm 0.07$ \\
\hline 6 & $13.03 \pm 0.01$ & $9.14 \pm 0.02$ & $1.92 \pm 0.19$ \\
\hline 7 & $14.01 \pm 0.01$ & $9.20 \pm 0.05$ & $2.26 \pm 0.12$ \\
\hline 8 & $15.02 \pm 0.01$ & $9.33 \pm 0.02$ & $1.96 \pm 0.20$ \\
\hline 9 (confirmatory test) & $25.24 \pm 0.01$ & $9.44 \pm 0.30$ & $2.33 \pm 0.28$ \\
\hline
\end{tabular}

TABLE II. SUMMARY OF RESULTS (SAMPLING PERIOD 2)

\begin{tabular}{|c|c|c|c|}
\hline Analysis no & $\begin{array}{c}\text { Amount of } \\
\text { NaOH (g) }\end{array}$ & pH & $\begin{array}{c}\text { Amount of Ag } \\
\text { recovered (g) }\end{array}$ \\
\hline 1 & $8.05 \pm 0.01$ & $8.82 \pm 0.00$ & $1.29 \pm 0.39$ \\
\hline 2 & $9.01 \pm 0.11$ & $8.96 \pm 0.01$ & $1.67 \pm 0.32$ \\
\hline 3 & $10.04 \pm 0.02$ & $9.04 \pm 0.02$ & $2.46 \pm 0.47$ \\
\hline 4 & $11.03 \pm 0.02$ & $9.09 \pm 0.01$ & $1.92 \pm 0.32$ \\
\hline 5 & $12.04 \pm 0.02$ & $9.02 \pm 0.11$ & $1.66 \pm 0.38$ \\
\hline 6 & $13.03 \pm 0.01$ & $9.13 \pm 0.15$ & $1.67 \pm 0.48$ \\
\hline 7 & $14.01 \pm 0.01$ & $9.29 \pm 0.03$ & $1.82 \pm 0.35$ \\
\hline 8 & $15.01 \pm 0.01$ & $9.35 \pm 0.02$ & $1.95 \pm 0.23$ \\
\hline
\end{tabular}

\section{B. Statisical analyses}

The ANOVA result shows that the amount of silver recovered by varying the amount of $\mathrm{NaOH}$ was significant with p-value $=0.000$ (sampling A). This implied that there were significant differences on the average amount of recovered crude silver between varying amounts of $\mathrm{NaOH}$ used (Table III). Further analysis using Tukey Test ("Figure 6) was done in order to determine at which specific means of silver recovered with varying amount of $\mathrm{NaOH}$ exhibited significant difference.

TABLE III. SUMMARY OF ANOVA ANALYSES

\begin{tabular}{|c|c|c|c|}
\hline Sampling & F value & P value & Decision \\
\hline A & 16.12 & 0.000 & Significant difference \\
\hline B & 2.45 & 0.066 & No significant difference \\
\hline
\end{tabular}

\begin{tabular}{|c|c|c|c|c|c|c|c|}
\hline $\begin{array}{l}\text { Amt. } \\
\mathrm{NaOH}\end{array}$ & 1 & 2 & 3 & 4 & 5 & 6 & 7 \\
\hline- & $\begin{array}{r}-0.0403 \\
0.9537\end{array}$ & & & & & & \\
\hline 3 & $\begin{array}{l}0.3197 * \\
1.3137\end{array}$ & $\begin{array}{r}-0.1370 \\
0.8570\end{array}$ & & & & & \\
\hline 4 & $\begin{array}{r}-0.0937 \\
0.9003\end{array}$ & $\begin{array}{r}-0.5503 \\
0.4437\end{array}$ & $\begin{array}{r}-0.9103 \\
0.0837\end{array}$ & & & & \\
\hline 5 & $\begin{array}{l}0.3330 * \\
1.3270\end{array}$ & $\begin{array}{r}-0.1237 \\
0.8703\end{array}$ & $\begin{array}{r}-0.4837 \\
0.5103\end{array}$ & $\begin{array}{r}-0.0703 \\
0.9237\end{array}$ & & & \\
\hline 6 & $\begin{array}{l}0.5463^{*} \\
1.5403\end{array}$ & $\begin{array}{l}0.0897 * \\
1.0837\end{array}$ & $\begin{array}{r}-0.2703 \\
0.7237\end{array}$ & $\begin{array}{l}0.1430 * \\
1.1370\end{array}$ & $\begin{array}{r}-0.2837 \\
0.7103\end{array}$ & & \\
\hline 7 & $\begin{array}{l}0.8863^{*} \\
1.8803\end{array}$ & $\begin{array}{l}0.4297 * \\
1.4237\end{array}$ & $\begin{array}{l}0.0697 * \\
1.0637\end{array}$ & $\begin{array}{l}0.4830 * \\
1.4770\end{array}$ & $\begin{array}{l}0.0563^{*} \\
1.0503\end{array}$ & $\begin{array}{r}-0.1570 \\
0.8370\end{array}$ & \\
\hline 8 & $\begin{array}{l}0.57977^{*} \\
1.5737\end{array}$ & $\begin{array}{l}0.1230 * \\
1.1170\end{array}$ & $\begin{array}{r}-0.2370 \\
0.7570\end{array}$ & $\begin{array}{l}0.1763^{*} \\
1.1703\end{array}$ & $\begin{array}{r}-0.2503 \\
0.7437\end{array}$ & $\begin{array}{r}-0.4637 \\
0.5303\end{array}$ & $\begin{array}{r}-0.8037 \\
0.1903\end{array}$ \\
\hline
\end{tabular}

* sionificant difference

Fig. 6. Tukey Test on the Average Amount of Silver Recovered with Varying Amount of $\mathrm{NaOH}$ in Sampling A

It can be extrapolated from Figure 4 that their was a significant difference between the means/averages of silver recovered using $\mathrm{NaOH}$ at $8.01 \mathrm{~g}-10.00 \mathrm{~g}, 8.01 \mathrm{~g}-12.08 \mathrm{~g}, 8.01$ g- 13.03 g, 8.01 g-14.01 g, 8.01 g-15.02 g, 9.07 g-13.03 g, 9.07 g-14.01 g, 9.07 g-15.02 g, 10.00 g- 14.01 g, 11.03 g- 13.03 g, $11.03 \mathrm{~g}-14.01 \mathrm{~g}, 11.03 \mathrm{~g}-15.02 \mathrm{~g}, 12.08 \mathrm{~g}-14.01 \mathrm{~g}$ respectively. The result in sampling A only showed that the amount of $\mathrm{NaOH}$ that can produce more crude silver was within the range of $10.00 \mathrm{~g}$ to $15.00 \mathrm{~g}$. For sampling B, statically the results showed that the amount of silver recovered in sampling B do not differ significantly with $p$-value $=0.066$. Although the $p$ value confirms no significant difference since it exceeds the critical value at 0.05 , the raw data obtained in sampling B have shown a significant rise on the amount of silver recovered by using approximately $10.00 \mathrm{~g}$ to $15.00 \mathrm{~g}$ of $\mathrm{NaOH}$. Notably, data used for One Way -ANOVA were those averages amount of the three trials done and thus if lower or higher values were present of recovered crude silver the resulting averages considerably may be pulled. 


\section{Optimum condition}

Figures 7 and 8 present the graph showing amount of $\mathrm{NaOH}$ and $\mathrm{pH}$ against the amount of silver recovered. It can be extrapolated in the present findings that optimum amount of crude silver can be recovered at $\mathrm{pH}$ approximately 9 (Figure 7) and $\mathrm{NaOH}$ approximately $10 \mathrm{~g}$ (Figure 8). The method used in this study for fixer waste was not established in literature, considering that alkaline treatment was commonly used in waste X-ray films analysis [5]. However, the use of other alkali like potassium boro-hydride (KBH4) at $\mathrm{pH} 8 \sim 9$ showed $98.0 \%$ and $95.8 \%$ silver recovery [2]. The same $\mathrm{pH}$ in this study similarly showed optimum condition for recovery.

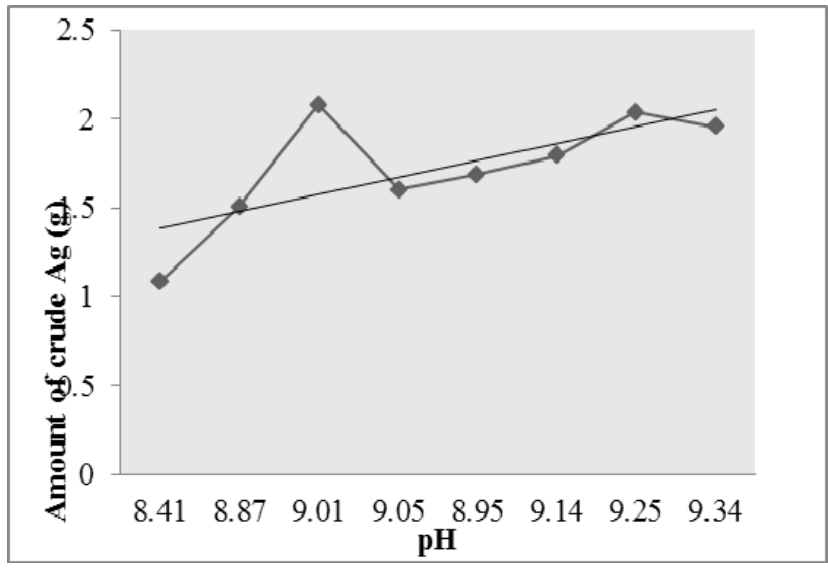

Fig. 7. Relationship between $\mathrm{pH}$ and amount of crude silver recovered

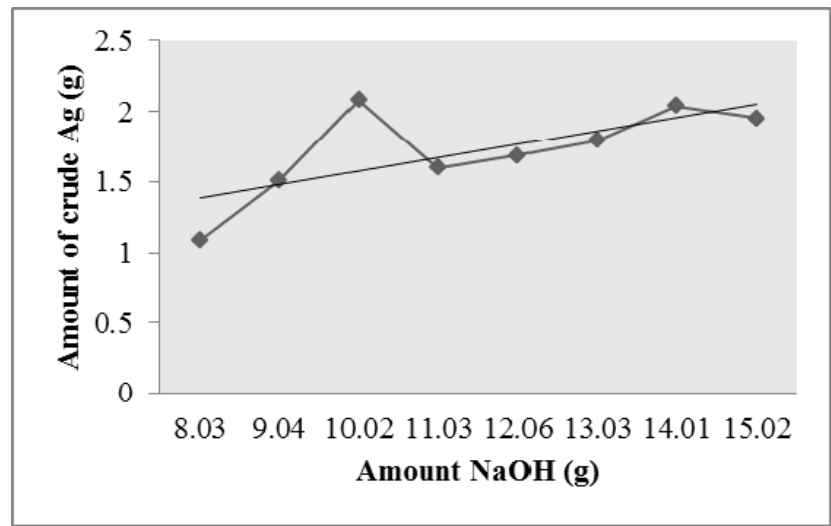

Fig. 8. Relationship between amount of alkaline reagent used and the amount of crude silver recovered

\section{CONCLUSIONS}

The study investigates a chemical method of silver recovery from $\mathrm{x}$-ray processing fixer waste by alkaline treatment using sodium hydroxide $(\mathrm{NaOH})$. The samples considered were taken from selected hospitals and radiology centers in Philippines. Overall, approximately $10.00-15.00 \mathrm{~g} \mathrm{NaOH}$ is found to be the optimal practical amount of precipitating agent for the recovery of crude silver from a specified volume of x-ray fixer waste. Recovery improvement below and above the above range was insignificant as far as the amount of crude silver produced is concerned. The $\mathrm{NaOH}$ precipitation method works under basic condition with $\mathrm{pH}$ of 9 to 12 .

\section{REFERENCES:}

[1] S. Shankar, S. V. More, R. S. Laxman, "Recovery of silver from waste X-ray film by alkaline protease from Conidiobolus coronatus", Kathmandu University Journal of Science, Engineering and Technology, Vol. 6, No. 1, pp. 60-69, 2011

[2] H. Zhouxiang, W. Jianying, Z. Ma, H. Jifan, "A method to recover silver from waste X-ray films with spent fixing bath", Hydrometallurgy, Vol. 92, No. 3, pp. 148-151, 2008

[3] V. I. E. Ajiwe, I. E. Anyadiegwu, "Recovery of silver from industrial wastes, cassava solution effects", Separation and Purification Technology, Vol. 18, No. 2, pp. 89-92, 2000

[4] N. Nakiboglu, D. Toscali, I. Yasa, "Silver recovery from waste photographic films by using enzymatic method", Turkish Journal of Chemistry, Vol. 25, No. 3, pp. 349-353, 2001

[5] N. Nakiboglu, D. Toscali, G. A. Nisli, "A novel silver recovery method from waste photographic films with $\mathrm{NaOH}$ stripping", Turkish Journal of Chemistry, Vol. 27, No. 1, pp. 127-133, 2003

[6] A. D. Bas, E. Y. Yazici, H. Deveci, "Recovery of silver from X-ray film processing effluents by hydrogen peroxide treatment", Hydrometallurgy, Vol. 121, pp. 22-27, 2012

[7] V. Choudhary, "Recovery of silver from used X-ray films by Aspergillus versicolor protease", Journal of Academia and Industrial Research, Vol. 2, No. 1, pp. 39-41, 2003

[8] J. Marinkovic, M. Korac, Z. Kamberovic, I. Matic, "Recycling of silver from exposed X-ray films", Acta Metallurgica Slovaca, Vol. 12, pp. 262-268, 2006

[9] P. A. Ramirez, V. E. Reyes, M. A. Veloz, "Silver recovery from radiographic films using an electrochemical reactor", International Journal of Electrochemical Science, Vol. 6, pp. 6151-6164, 2011

[10] J. P. Chen, L. L. Lim, "Recovery of precious metals by an electrochemical deposition method", Chemosphere, Vol. 60, No. 10, pp. 1384-1392, 2005

[11] J. Bentley, U.S. Patent No. 3,715,291. Washington, DC: U.S. Patent and Trademark Office. 1973

[12] R. Scheidegger, A. Zurrer, U.S. Patent No. 4,139,431. Washington, DC: U.S. Patent and Trademark Office, 1979

\section{AUTHORS PROFILE}

Van Ryan Kristopher R. Galarpe is presently purusing a $\mathrm{PhD}$ in Science Education-Chemistry in the University of Science and Technology of Southern Philippines. She is a graduate of MSc Environmental Science in the University of San Carlos, Cebu Philippines on 2013 under the Department of Science and Technology (DOST) scholarship grant. She also earned her BSc in Applied Physical Sciences (major Chemistry and Physics) in the University of Science and Technology of Southern Philippines (USTP) as academic scholar. Her research work experience focused on solid waste management, environmental chemistry and toxicology, science education, and environmental science.

Girlie D. Leopoldo is presently working as an Assistant Professor in the University of Science and Technology of Southern Philippines (USTP) under the Department of Chemistry. She earned her BSc in Chemistry and MSc in Chemistry from the Mindanao State University-Iligan Institute of Technology (MSU-IIT) in the Philippines. Her present work is focused mainly on environmental analytical chemistry which include water quality analysis. 